\title{
Gynaecomastie als eerste manifestatie van een testistumor
}

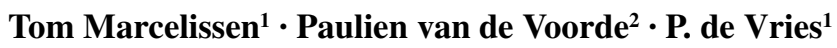

Published online: 12 October 2016

(C) The Author(s) 2016. This article is an open access publication.

Samenvatting In dit artikel beschrijven wij twee patiënten die zich presenteren met gynaecomastie als eerste symptoom van een testistumor. Histopathologisch onderzoek na orchidectomie toont het beeld van respectievelijk een seminoom en een Leydig-celtumor. Verschillende pathofysiologische mechanismen spelen een rol bij het ontstaan van gynaecomastie. In beide casussen verdween de gynaecomastie na orchidectomie.

Trefwoorden testistumor $\cdot$ gynaecomastie $\cdot$ seminoom . Leydig-celtumor

\section{Gynecomastia as a first symptom of a testicular tumor}

\begin{abstract}
In this case report we present two patients with gynecomastia as a first symptom of a testicular tumor. Histopathology showed a pure seminoma and Leydig cell tumor respectively. Different mechanisms can play a role in the origin of gynecomastia. In both patients, the gynecomastia disappeared after orchidectomy.
\end{abstract}

Keywords testicular tumor - gynecomastia $\cdot$ seminoma . Leydig cell tumor

drs. Tom Marcelissen

tmarcelissen@gmail.com

1 afdeling Urologie, Zuyderland Medisch Centrum, Heerlen, Nederland

2 Faculteit Geneeskunde, Universiteit Maastricht, Maastricht, Nederland

\section{Introductie}

Gynaecomastie wordt veroorzaakt door een verstoring in de balans tussen oestrogenen en androgenen. Er moet onderscheid worden gemaakt met pseudo-gyneacomastie, dat wordt veroorzaakt door adipositas (vetdepositie zonder klierproliferatie) of een mammacarcinoom. Gynaecomastie kan voorkomen bij endocrien actieve tumoren, metabole stoornissen en het gebruik van drugs of medicatie (tab. 1). De prevalentie van gynaecomastie is sterk leeftijdsafhankelijk en kan voorkomen als fysiologisch verschijnsel. Bij pasgeborenen komt gynaecomastie voor als gevolg van oestrogeenpassage door de placenta, in de puberteit door toegenomen productie van geslachtshormonen, en op oudere leeftijd door een combinatie van verminderde testiculaire functie en toegenomen aromataseactiviteit door relatieve toename van de vetmassa [1]. Omdat gynaecomastie een uiting kan zijn van een maligniteit, in het bijzonder een testiculaire kiemceltumor, wordt in de praktijk aangeraden om bij een patiënt met gynaecomastie de testes te onderzoeken.

Hoewel het testiscarcinoom een zeldzame aandoening is, is het bij jonge mannen tussen het $15 \mathrm{e}$ en $35 \mathrm{e}$ levensjaar de meest voorkomende kwaadaardige aandoening [2]. Jaarlijks wordt in Nederland de diagnose bij ongeveer 800 mannen gesteld. Ongeveer $95 \%$ van deze tumoren zijn kiemceltumoren. Het simultaan voorkomen van gynaecomastie bij een unilateraal testiscarcinoom doet zich voor in 2,5 tot $6 \%$ van de gevallen op het tijdstip van presentatie [3].

In dit artikel beschrijven we twee patiënten met gynaecomastie als eerste symptoom van een testistumor. 
Tabel 1 Differentiaaldiagnose van gynaecomastie.

pseudo-gynaecomastie (bij adipositas, mammacarcinoom)
fysiologisch (bij neonaten, in de puberteit, op oudere leeftijd)
pathologisch $\quad \begin{aligned} & \text { maligniteit (testis, bijnier, long) } \\ & \text { levercirrose } \\ & \text { hyperthyreoïdie } \\ & \text { hypogonadisme (Klinefelter, Kallmann, idiopathisch) } \\ & \text { medicatie (spironolacton, ketoconazol, digoxine, } \\ & \text { busulfan, tricyclische antidepressiva) } \\ & \text { drugs (marihuana, amfetamines) }\end{aligned}$
idiopathisch (in $>50 \%$ van de gevallen is er geen duidelijke oorzaak)

\section{Casus 1}

Op de polikliniek presenteert zich een 36-jarige man met een sinds enkele maanden bestaande zwelling van de linkermamma. Daarnaast heeft hij sinds enkele weken een zeurend gevoel in de rechterzijde van het scrotum. Op kinderleeftijd was er sprake van een niet-ingedaalde testis rechts; deze is destijds operatief hersteld middels een orchidopexie. Verder heeft hij een blanco voorgeschiedenis en gebruikt hij geen medicatie.

Bij lichamelijk onderzoek zien we een gezond ogende man, met een litteken inguïnaal rechts na orchidopexie. Bij onderzoek van het scrotum vinden we links een kleine testis zonder palpabele afwijkingen. Rechts wordt aan de caudale zijde van de testis een evidente massa gevoeld van enkele centimeters groot. Verder zijn er geen vergrote liesklieren palpabel. Bij onderzoek van de mammae wordt links een mobiele, elastische zwelling onder de tepel gevoeld, die past bij gynaecomastie.

Laboratoriumonderzoek levert de volgende resultaten (referentiewaarden): lactaatdehydrogenase (LDH) 209 U/1 (0-250), humaan choriongonadotrofin echografie laat een heterogene massa zien in de rechtertestis, verdacht voor maligniteit. Stadiëring middels CT-scan van thorax en abdomen laat geen aanwijzingen zien voor longmetastasen, abdominale lymfadenopathie dan wel skeletmetastasen.

De aangedane testis wordt vervolgens verwijderd door middel van een inguïnale orchidectomie. Histopathologisch onderzoek toont het beeld van een puur seminoom met maximale diameter van $2,5 \mathrm{~cm}$.

Postoperatief laboratoriumonderzoek toont een daling van het HCG conform de halfwaardetijd tot $<0,1 \mathrm{E} / \mathrm{l}$. De gynaecomastie verdween binnen enkele weken na de ingreep volledig.

\section{Casus 2}

Op de polikliniek presenteert zich een 33-jarige mannelijke patiënt met een sinds enkele jaren bestaande zwelling van de klierschijf van beide borsten. Primair deed de zwelling zich enkel voor aan de rechterzijde. Behoudens mammografisch onderzoek (zonder afwijkingen) van de rechtermamma, heeft er destijds geen aanvullend onderzoek plaatsgevonden. De patiënt werd nu vanwege bilaterale borstvorming vanuit de huisartsenpraktijk verwezen naar de polikliniek Heelkunde voor nader onderzoek. Echografisch onderzoek bevestigt forse bilaterale gynaecomastie zonder verdenking op een mammacarcinoom. Afgezien van bilaterale borstvorming klaagde patiënt over erectiele disfunctie. Patiënt onderging op kinderleeftijd een orchidopexie rechts vanwege niet-ingedaalde testis. De verdere voorgeschiedenis is niet bijdragend en patiënt gebruikt geen medicatie. Via de polikliniek Heelkunde wordt patiënt doorverwezen naar onze polikliniek vanwege afwijkende bevindingen bij echografisch onderzoek van de linkertestis.

Bij lichamelijk onderzoek wordt rechts een atrofische testis gevonden, status na orchidopexie. Links wordt een palpabele massa van enkele centimeters gevonden die uitgaat van de testis. Onderzoek van het abdomen is niet afwijkend en er worden geen palpabele lymfeklieren gevonden.

Laboratoriumonderzoek laat normale serumwaarden van de tumormarkers zien $(\mathrm{HCG}<0,1 \mathrm{E} / 1, \mathrm{LDH} 150 \mathrm{U} / \mathrm{L}$ en AFP 2,1 kU/l). Het testosterongehalte bedraagt 10,9 nmol/1 $(6,7-29,0)$.

Echografisch onderzoek laat een heterogene massa in de linkertestis zien, verdacht voor een maligniteit. Verder aanvullend onderzoek door middel van een CT abdomen/ thorax laat geen longmetastasen of abdominale lymfadenopathie zien. De afwijkende testis wordt vervolgens verwijderd door middel van een orchidectomie. Histopathologisch onderzoek toont een Leydig-celtumor met een diameter van $2,5 \mathrm{~cm}$.

Bij lichamelijk onderzoek na enkele weken op de polikliniek bemerken we een evidente afname in de gynaecomastie. Laboratoriumonderzoek toont geen afwijkende waarden.

\section{Beschouwing}

Gynaecomastie is het gevolg van een verstoorde balans tussen bioactieve oestrogenen en testosteron. Testiculaire oestrogeenproductie vindt hoofdzakelijk plaats in de Leydigcellen, maar in minder mate ook in de Sertoli-cellen. Extragonadale aromatisering van testosteron kan plaatsvinden in vele weefsels, waaronder de borstklier (fig. 1). Daarnaast vindt er in de bijnier productie plaats van androsteendion, een hormoon dat een rol speelt bij de synthese van testosteron, maar dat ook via aromatisering kan worden omgezet in oestrogeen. 
Figuur 1 Extragonadale aromatisering van testosteron in borstweefsel.

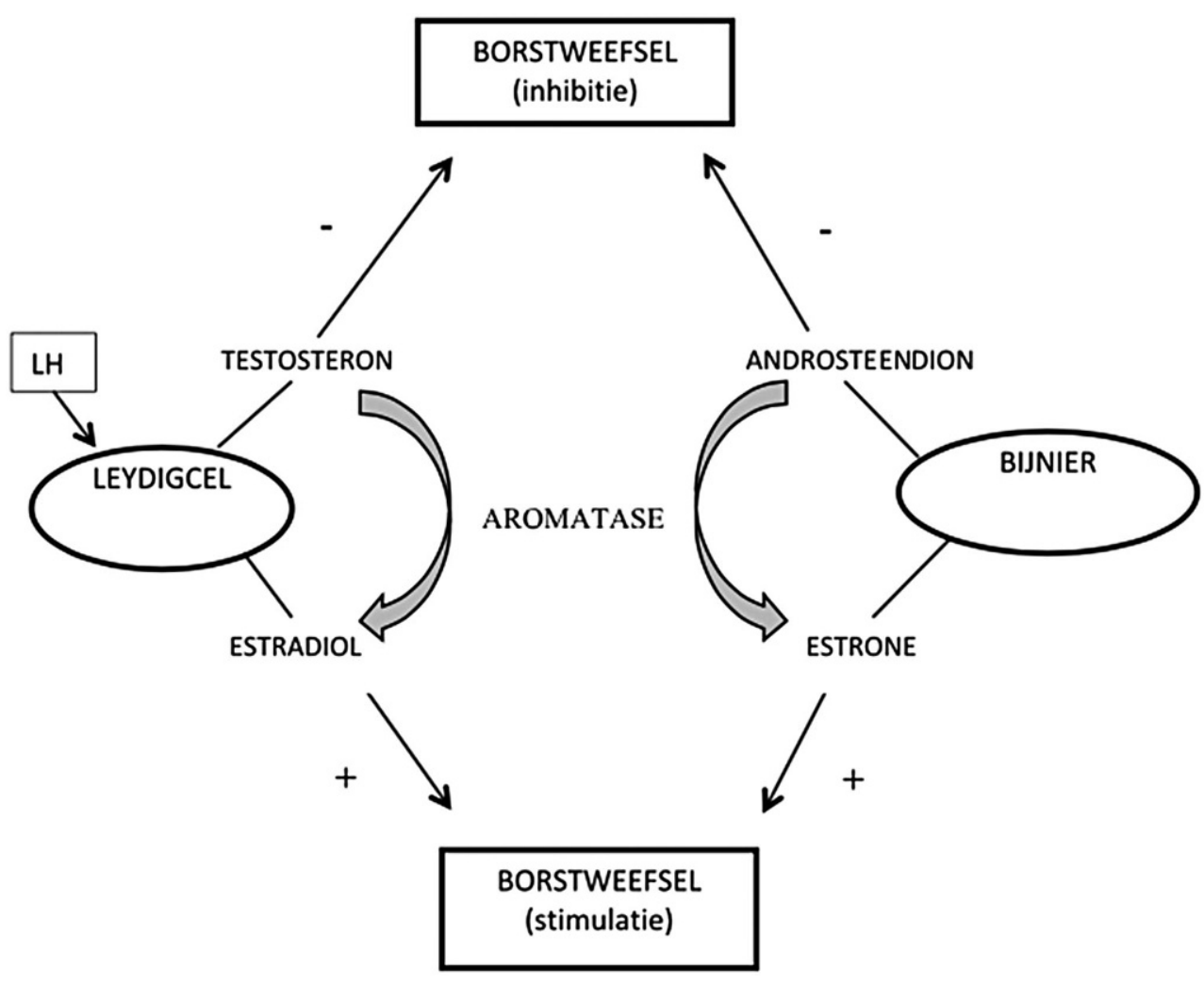

Gynaecomastie kan zowel uni- als bilateraal voorkomen. Lokale verschillen in het aantal oestrogeenreceptoren in het borstweefsel geven een verklaring voor het feit dat gynaecomastie veelal eenzijdig voorkomt. Onze twee patiënten presenteren zich beiden met gynaecomastie als eerste symptoom van een testistumor.

In patiënt 1 gaat het om sinds enkele weken bestaande unilaterale gynaecomastie, met een verhoogde HCG-spiegel (129,6 E/l). Histopathologisch onderzoek toonde een seminoom. HCG is sterk verwant aan LH en delen dezelfde receptor (LH-HCG-receptor). Vergeleken met LH heeft HCG een veel langere halfwaardetijd en een potenter effect op de LH-HCG-receptor, wat leidt tot verhoging van de aromataseactiviteit in de interstitiële cellen [4]. Dit zorgt voor meer aanmaak van de androgene voorlopers E1oestron en E2-oestradiol, wat resulteert in de vorming van secundaire geslachtskenmerken, waaronder borstontwikkeling. Verhoogde HCG-spiegels kunnen ook indirect leiden tot inhibitie van LH-secretie in de hypofyse.

In tegenstelling tot de eerste patiënt, gaat het bij de tweede patiënt om een sedert jaren bestaande bilaterale gynaecomastie, met klachten van erectiele disfunctie. De serum-tumormarkers waren normaal. Histopathologisch onderzoek toonde een Leydig-celtumor.

Leydig-celtumoren secerneren toegenomen hoeveelheden $\mathrm{E} 2$ en aromatiseren meer androgeenprecursoren van oestrogenen [5, 6]. Bij volwassenen kan de testosteronproductie worden verlaagd, omdat de toegenomen E2-spiegels de gonadotropine secretie inhiberen, een inhibitie die leidt tot een secundair hypogonadisme. Gynaecomastie wordt in 20-30\% van de gevallen gezien bij patiënten met Leydigceltumoren van de testes [7]. Leydig-celtumoren komen niet vaak voor (1-3\% van alle testistumoren) $[8,9]$ en worden meestal gevonden bij 26- tot 35-jarige mannen die zich presenteren met een testiculaire massa, gynaecomastie, erectiele disfunctie en libidoverlies. Ondanks de lage incidentie, zijn het de meest voorkomende interstitiële testistumoren. Het merendeel van de Leydig-celtumoren is benigne. Ongeveer $10 \%$ vertoont een maligne aspect en metastaseert naar retroperitoneale lymfeklieren, lever, longen en skelet. De kans op maligniteit wordt voornamelijk bepaald door de grootte (diameter groter dan $5 \mathrm{~cm}$ ), lymfangio-invasie of ingroei van de weke delen [10]. Gezien het overwegend benigne karakter van Leydig-celtumoren kan worden overwogen om bij patiënten met kleine tumoren $(<2 \mathrm{~cm})$ en negatieve tumormarkers, een inguïnale exploratie uit te voeren met enucleatie en vriescoupe. Met deze strategie kan mogelijk een deel van de testis worden gespaard.

Hoewel gynaecomastie na orchidectomie vaak vanzelf verdwijnt, kan in ernstige gevallen verdere behandeling nodig zijn. Chirurgische interventie kan worden overwogen wanneer de gynaecomastie niet spontaan verdwijnt, wanneer de gynaecomastie aanzienlijke ongemakken of psychologische stress oplevert voor de patiënt of wanneer het borstweefsel zich in de fibrotische fase bevindt $[11,12]$. 


\section{Conclusie}

Gynaecomastie kan het eerste symptoom zijn van een occulte testistumor. Verschillende pathofysiologische mechanismen kunnen hierbij een rol spelen. Een zorgvuldige analyse is essentieel bij elke man die zich presenteert met borstvorming. Na behandeling van de testistumor neemt de gynaecomastie in de meeste gevallen af.

Open Access This article is distributed under the terms of the Creative Commons Attribution 4.0 International License (http:// creativecommons.org/licenses/by/4.0/), which permits unrestricted use, distribution, and reproduction in any medium, provided you give appropriate credit to the original author(s) and the source, provide a link to the Creative Commons license, and indicate if changes were made.

\section{Literatuur}

1. Braunstein GD. Gynecomastia. N Engl J Med. 1993;328:490-5.

2. Siegel R, Ward E, Brawley O, Jemal A. Cancer statistics, 2011: the impact of eliminating socioeconomic and racial disparities on premature cancer deaths. CA Cancer J Clin. 2011;61(4):212.

3. Narula HS, Carlson HE. Gynaecomastia, pathophysiology, diagnosis and treatment. Nat Rev Endocrinol. 2014;11(10):684-98.
4. Jiang X, Dias JA, He X. Structural biology of glycoprotein hormones and their receptors: insights to signaling. Mol Cell Endocrinol. 2014;382:424-51.

5. Bercovici JP, Nahoul K, Ducasse M, Tater D, Kerlan V, Scholler R. Leydig cell tumor with gynecomastia: further studies - the recovery after unilateral orchidectomy. J Clin Endocrinol Metab. 1985;61(5):957.

6. Braunstein GD. Aromatase and gynecomastia. Endocr Relat Cancer. 1999;6(2):315.

7. Bercovici JP, Tater D, Khoury S, Charles JF, Floch J, Leroy JP. Leydig cell tumor with gynecomastia: hormonal effects of an estrogenproducing tumor. J Clin Endocrinol Metab. 1981;53(6):1291.

8. Agarwal PK, Palmer JS. Testicular and paratesticular neoplasms in prepubertal males. J Urol. 2006;176:875.

9. Young RH. Testicular tumors - some new and a few perennial problems. Arch Pathol Lab Med. 2008;132:548.

10. Al-Agha OM, Axiotis CA. An in-depth look at Leydig cell tumor of the testis. Arch Pathol Lab Med. 2007;131:311.

11. Gruntmanis U, Braunstein GD. Treatment of gynecomastia. Curr Opin Investig Drugs. 2001;2:643.

12. Gikas PH, Mokbel K. Management of gynaecomastia: an update. Int J Clin Pract. 2007;61:1209.

drs. Tom Marcelissen aios urologie

Paulien van de Voorde masterstudent geneeskunde

dr. P. de Vries uroloog 